\title{
Sintesis dan Sifat Penyerapan Gelombang Mikro Grafena Alam Berbahan Dasar Arang Bambu Kuning (Bambusa Vulgaris), Ori (Bambusa Bambos Miq) dan Petung (Dendrocalamus Asper)
}

\author{
Mashuri*, Luthfiati Ningsih, M. Zainul Asrori, Triwikantoro, dan Darminto \\ Departemen Fisika, Fakultas Sains dan Analitika Data, Institut Teknologi Sepuluh Nopember \\ Kampus ITS Keputih Sukolilo Surabaya, 60111
}

Intisari

\begin{abstract}
Telah dilakukan sintesis serbuk grafena alam berfasa reduced Graphene Oxide (rGO) dari arang bambu Kuning (Bambusa Vulgaris), Ori (Bambusa Bambos Miq) dan Petung (Dendrocalamus Asper) sebagai bahan penyerap gelombang mikro dengan metode karbonisasi pada temperatur $600^{\circ} \mathrm{C}$ selama 45 menit. Serbuk grafena alam berfasa rGO dikarakterisasi dengan XRD, berupa lembaran tipis berskala mikro dikarakterisasi dengan SEM dan memiliki konduktivitas listrik $5,57 \times 10^{-6} \mathrm{~S} / \mathrm{cm}$. Grafena alam berfasa rGO memiliki densitas rendah, dielectric loss yang kuat dan specific surface area yang besar. Penyerapan gelombang mikro pada frekuensi 8-12 GHz diukur menggunakan alat Vector Network Analyzer (VNA). Hasil pengukuran menunjukkan nilai maximum reflection loss $\left(\mathrm{RL}_{m}\right)$ dan matching frequency $\left(\mathrm{f}_{m}\right)$ serbuk grafena alam berfasa rGO dari arang bambu berturut-turut Petung ( $\left.\mathrm{RL}_{m 1}=-52,88 \mathrm{~dB}, \mathrm{f}_{m 1}=8,56 \mathrm{GHz}, \mathrm{RL}_{m 2}=-26,33 \mathrm{~dB}, \mathrm{f}_{m 2}=10,18 \mathrm{GHz}\right)$, Ori $\left(\mathrm{RL}_{m 1}\right.$ $\left.=-45,46 \mathrm{~dB}, \mathrm{f}_{m 1}=8,40 \mathrm{GHz}, \mathrm{RL}_{m 2}=-25,15 \mathrm{~dB}, \mathrm{f}_{m 2}=10,18 \mathrm{GHz}\right)$ dan Kuning $(\mathrm{RLm} 1=-34,15 \mathrm{~dB}, \mathrm{fm} 1$ $=8,40 \mathrm{GHz}, \mathrm{RL}_{m 2}=-25,46 \mathrm{~dB}, \mathrm{f}_{m 2}=10,16 \mathrm{GHz}$ ) pada ketebalan optimum 0,6 mm. Bambu Petung sangat potensial dijadikan sebagai bahan penyerap gelombang mikro dalam bentuk grafena alam berfase rGO bersifat ramah lingkungan, relatif murah dan sederhana pembuatannya.
\end{abstract}

\begin{abstract}
Synthesis of reduced Graphene Oxide (rGO) natural graphene powder from Kuning bamboo (Bambusa Vulgaris), Ori (Bambusa Bambos Miq) and Petung (Dendrocalamus Asper) has been done as a microwave absorbent with carbonization method at $600^{\circ} \mathrm{C}$ for 45 minutes. rGO-based natural graphene powder was characterized by $\mathrm{x}$-ray diffraction (XRD), in the form of thin micro-scale sheets characterized by scanning electron microscopy $(\mathrm{SEM})$ and has an electrical conductivity of $5.57 \times 10^{-6} \mathrm{~S} / \mathrm{cm}$. rGO-based natural graphene has low density, strong dielectric loss and large specific surface area. The absorption of microwaves at frequencies from 8-12 GHz was measured using a vector network analyzer (VNA). The measurement results show that the value of maximum reflection loss (RLm) and matching frequency $(\mathrm{fm})$ of natural graphene powder rGO-based from bamboo charcoal in a row Petung $\left(\mathrm{RL}_{m 1}=-52.88 \mathrm{~dB}, \mathrm{f}_{m 1}=8.56 \mathrm{GHz}, \mathrm{RL}_{m 2}=-26.33 \mathrm{~dB}, \mathrm{f}_{m 2}=10.18 \mathrm{GHz}\right)$ , Ori (RL $\left.\mathrm{RL}_{m 1}=-45.46 \mathrm{~dB}, \mathrm{f}_{m 1}=8.40 \mathrm{GHz}, \mathrm{RL}_{m 2}=-25.15 \mathrm{~dB}, \mathrm{f}_{m 2}=10.18 \mathrm{GHz}\right)$ dan Kuning (RLm1 $=-34.15$ $\mathrm{dB}, \mathrm{fm} 1=8.40 \mathrm{GHz}, \mathrm{RL}_{m 2}=-25.46 \mathrm{~dB}, \mathrm{f}_{m 2}=10.16 \mathrm{GHz}$ ) at an optimum thickness of $0.6 \mathrm{~mm}$. Petung Bamboo is very potential to be used as an absorbent material for microwaves in the form of natural graphene with an rGO phase that is environmentally friendly, relatively inexpensive and simple to manufacture.
\end{abstract}

Keywords: bamboo; microwaves absorbent material; natural graphene' reduced graphene oxide.

*Corresponding author: mash@physics.its.ac.id

http://dx.doi.org/10.12962/j24604682.v16i3.6973

2460-4682 (CDepartemen Fisika, FSAD-ITS

\section{PENDAHULUAN}

Pertahanan negara merupakan hal yang paling utama dalam menjaga kedaulatan bangsa. Pertahanan akan kuat ditentukan oleh kuantitas dan kualitas dari alat utama sistem senjata. Kualitas alat utama sistem senjata ditentukan oleh perkembangan sains dan teknologi modern. Perkembangan sains dan teknologi modern dalam bidang komunikasi gelombang mikro dalam kepentingan militer dipengaruhi oleh sistem pengoperasian meliputi perangkat elektronik dan manusia sebagai operatornya. Salah satu pengembangan sains dan teknologi alat utama sistem senjata modern adalah teknologi siluman (stealth technology) berupa pembuatan bahan penyerap gelombang radar [1]. 
Penyerapan gelombang radar mencakup dua hal yaitu interferensi dan radiasi, di mana gelombang radar dapat diserap secara efektif dengan merubah energi gelombang radar menjadi panas atau disipasi melalui interferensi. Suatu bahan penyerap gelombang radar yang ideal harus memiliki daya absorbsi yang kuat, absorbsi pada selang frekuensi lebar, densitas rendah dan tipis [2-3]. Kemampuan penyerapan gelombang radar suatu bahan ditentukan nilai magnetic loss, dielectric loss, dan karakteristik impedansi matching frequency. Secara konvensional telah banyak diteliti bahan dengan nilai magnetic loss yang tinggi dari keluarga magnetik namun densitas tinggi seperti ferit, cobalt, nikel dan iron carbonyl. Bahan yang memiliki dielectric loss tinggi, densitas rendah dan tipis dapat ditemui pada keluarga karbon [4-5].

Bahan magnetik dan dielektrik umumnya dibuat dari bahan komersial yang harganya relatif mahal dengan proses yang tidak sederhana. Grafena merupakan salah satu keluarga karbon yang memiliki densitas rendah, tipis, konduktivitas listrik tinggi, tahan korosi, dan luas permukaan yang besar sangat cocok untuk dibuat sebagai material penyerap gelombang radar[6-7]. Saat ini terdapat tantangan yang besar bagaimana pembuatan dan dari bahan dasar apa grafena dibuat untuk menjadikannya sebagai bahan penyerap gelombang radar yang ideal.

Dalam makalah ini dilaporkan hasil penelitian pembuatan penyerap gelombang radar berbahan grafena alam dari batang bambu Kuning, Ori, dan Petung yang disintesis dengan metode karbonisasi. Grafena alam yang dibuat sebagai penyerap gelombang radar berfasa rGO dengan variasi ketebalan $0,3 \mathrm{~mm}, 0,6 \mathrm{~mm}$ dan $0,9 \mathrm{~mm}$.

\section{METODOLOGI}

\section{Sintesis grafena alam}

Bahan baku yang digunakan untuk pembuatan serbuk rGO adalah arang bambu dari varian bambu Kuning, Ori, dan Petung. Bambu yang digunakan dalam penelitian ini adalah bambu yang berusia 3-4 tahun karena pada usia ini bambu memiliki kadar selulosa berkisar antara 42,4-53,6\% dan lignin berkisar 19,8-26,6\% yang banyak dengan kandungan karbon yang tinggi [8]. Pembuatan arang bambu dilakukan dengan menggunakan metode karbonisasi dengan tahapan yang sama untuk ketiga varian bambu yang bertujuan untuk menghasilkan karbon dan menghilangkan unsur non karbon.

Tahapan awal dilakukan pemilihan batang bambu pada bagian pangkal yang kering dan telah dikupas kulitnya. Untuk menghilangkan kandungan air dilakukan dehidrasi dalam furnace Nabertherm pada temperatur $120^{\circ} \mathrm{C}$ selama 24 jam dan mengoptimalkan proses karbonisasi. Sampel batang bambu yang telah kering selanjutnya dibakar pada temperatur $1000^{\circ} \mathrm{C}$ dalam lingkungan atmosfir terbuka untuk menghasilkan arang bambu secara karbonisasi. Arang bambu digerus secara mekanik hingga dalam bentuk serbuk dan dilakukan pemanasan pada temperatur $600^{\circ} \mathrm{C}$ selama 45 menit dalam furnace Nabertherm untuk mendapatkan kandungan karbon yang tinggi. Serbuk arang bambu digerus ulang dan dihomogenkan menjadi ukuran mesh 200 . Untuk memisahkan serbuk arang hasil pemanasan dengan abu dan impuritas lainnya, dilakukan pencucian menggunakan Ultrasonic Cleaner dan media aquades selama 5 jam. Prinsip kerja ultrasonic cleaner adalah menggunakan gelombang bunyi dengan frekuensi tinggi yang menyebabkan adanya gesekan antar partikel. Gesekan antar partikel akan mereduksi ukuran partikel sehingga menjadi ukuran partikel lebih pipih dan kecil. Abu dan impuritas lainnya yang memiliki massa jenis lebih kecil daripada arang akan mengapung dipermukaan dan karbon akan mengendap. Pengendapan serbuk arang bambu dilakukan selama 2 hari dan dikeringkan dalam ruang terbuka. Selanjutnya serbuk arang bambu dijadikan sebagai bahan grafena alam dengan kandungan karbon tinggi sebagai bahan baku penyerap gelombang mikro.

\section{Karakterisasi grafena alam}

Serbuk grafena alam hasil sintesis dengan metode karbonisasi dari bahan arang bambu Kuning, Ori dan Petung dilakukan karakterisasi gugus fungsi, fase, morfologi dan konduktivitas listrik. Karakterisasi gugus fungsi dilakukan menggunakan FTIR (tipe 8400S Shimadzu), fase grafena alam diuji menggunakan XRD (Philips X-Pert Multi Purpose Diffractometer System) dengan anode Cu, tipe PW 3050/60, tegangan $40 \mathrm{kV}$ dengan arus 30 watt. Morfologi serbuk grafena alam diamati menggunakan SEM-EDX (EVO MA 10) dan pengukuran konduktivitas listrik dilakukan dengan LCR meter two point probe. Karakterisasi penyerapan gelombang mikro dilakukan dengan mengukur nilai Reflection Loss menggunakan Vector Network Analyzer (VNA) (Advantest R-3770) pada frekuensi 8-12 GHz dengan ketebalan sampel uji 0,3 mm, 0,6 mm dan $0,9 \mathrm{~mm}$.

\section{HASIL DAN PEMBAHASAN}

\section{Analisis gugus fungsi, fase, morfologi dan konduktivitas listrik dari grefena alam}

Hasil pengujian gugus fungsi dari serbuk grafena alam dari arang bambu Kuning, Ori dan Petung berupa spektra FTIR ditunjukkan Gambar 1. Ikatan utama dari arang bambu ini adalah ikatan karbon tunggal C-C dan ikatan karbon rangkap $\mathrm{C}=\mathrm{C}$, namun juga ada ikatan lain yaitu $\mathrm{C}-\mathrm{H}, \mathrm{C}-\mathrm{O}, \mathrm{C}=\mathrm{O}$, dan $=\mathrm{C}-\mathrm{H}$. Ketiga jenis arang bambu memiliki ikatan gugus fungsi yang utama sama namun dengan bilangan gelombang yang berbeda yang disebabkan oleh perbedaan kandungan selulosa, lignin, pentosan ditunjukkan Tabel I. Ikatan karbon tunggal hanya dimiliki arang bambu Petung pada bilangan gelombang $1455,56 \mathrm{~cm}^{-1}$ dalam gugus alkana dengan jenis senyawa aromatik. Jika ikatan tunggal C-C membentuk cincin disebut sikloalkana yang termasuk hirokarbon jenuh. Alkana merupakan senyawa nonpolar dan tidak reaktif sehingga gaya tarikmenarik antar molekul lemah. Ikatan karbon pada ikatan tunggal C-C adalah ikatan sigma $(\sigma)$ yang memiliki energi ikat sebesar $524 \mathrm{~kJ} / \mathrm{mol}$, sehingga diperlukan energi tinggi dengan pemanasan untuk memutuskan ikatannya.

Ikatan utama karbon dari ketiga jenis arang bambu adalah ikatan karbon rangkap $\mathrm{C}=\mathrm{C}$. Arang bambu Petung memiliki 
TABEL I: Gugus fungsi dalam arang bambu Ori, Kuning dan Petung hasil uji dengan FTIR.

\begin{tabular}{llll}
\hline \hline \multicolumn{2}{c}{ Bilangan Gelombang $\left(\mathrm{cm}^{-1}\right)$} & Gugus \\
Petung & Ori & Kuning & Fungsi \\
\hline & - & 2358,01 & CH asimetri alkana \\
2358,41 & 1679,15 & - & C=O aldehid dan keton \\
- & 1557,57 & 1548,50 & $\mathrm{C}=\mathrm{C}$ cincin benzena \\
1567,$81 ; 1538,56$ & - & - \\
1557,$25 ; 1505,70$ & - & - & CC alkana \\
1455,56 & - & 1030,59 & CO alkohol dan fenol \\
1099,65 & 1089,19 & - \\
877,58 & 871,$29 ; 792,61-$ & -CH out of bending alkena \\
& $751,45873,10$ & - &
\end{tabular}

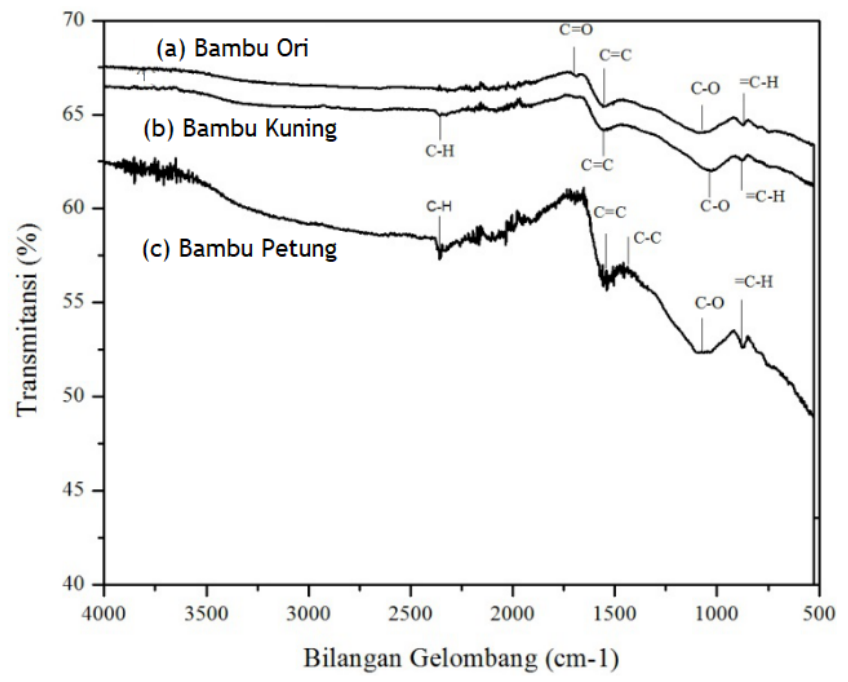

Gambar 1: Spektra FTIR dari arang bambu.

TABEL II: Nilai konduktivitas listrik arang bambu berfase rGO.

\begin{tabular}{cc}
\hline $\begin{array}{c}\text { Arang bambu Konduktivitas Listrik } \\
(\mathrm{rGO})\end{array}$ & $\begin{array}{c}\text { K } \\
\times 10^{-6}(\mathrm{~S} / \mathrm{cm})\end{array}$ \\
\hline & \\
Ori & 5,56 \\
Petung & 5,59 \\
Kuning & 5,58 \\
\hline
\end{tabular}

ikatan karbon rangkap $\mathrm{C}=\mathrm{C}$ pada empat daerah serapan yang berbeda, menunjukan kandungan ikatan rangkap $\mathrm{C}=\mathrm{C}$ lebih banyak dibanding arang bambu Kuning dan Ori. Ikatan karbon rangkap $\mathrm{C}=\mathrm{C}$ dalam keadaan terhibridisasi $\mathrm{sp}^{2}$ membentuk struktur reduced Graphene Oxide. Hibridisasi $\mathrm{sp}^{2}$ merupakan dasar dari struktur grafena dan senyawa aromatik dalam struktur grafit. Selain kedua jenis ikatan karbon tunggal dan rangkap, terdapat gugus karbonil $\mathrm{C}=\mathrm{O}$ yang hanya dimiliki bambu Ori pada daerah serapan $1679,15 \mathrm{~cm}^{-1}$. Gugus karbonil berbentuk planar sekeliling atom karbon $\mathrm{sp}^{2}$ trigonal. Ikatan rangkap karbon dan oksigen ini mengandung ikatan phi dalam ikatan rangkapnya. Gugus karbonil ini lebih polar dari pada ikatan tunggal C-O karena ikatan phi yang membentuk ikatan rangkap dengan karbon lebih mudah tertarik ke atom oksigen yang lebih elektronegatif dari pada elektron sigma dari ikatan $\mathrm{C}-\mathrm{O}$. Ikatan regangan $\mathrm{C}-\mathrm{O}$ ini termasuk dalam gugus fungsi alkohol dan fenol. Ikatan regangan C-O terdapat pada ketiga jenis bambu dengan daerah serapan yang berbeda.

Ikatan lain dalam arang ketiga bambu adalah tekukan keluar bidang (out of plane bending) ikatan = $\mathrm{C}-\mathrm{H}$ dalam senyawa aromatik. Adanya salah satu ikatan $=\mathrm{C}-\mathrm{H}$ yang termasuk dalam senyawa aromatik menunjukkan karbon yang dihasilkan dari arang bambu ini berikatan rangkap dengan atom lain dan berikatan kovalen tunggal dengan hidrogen yang merupakan bagian dari subtitusi dalam struktur benzena. Masing-masing posisi puncak dalam rentang tersebut menunjukkan tekukan dalam bidang $=\mathrm{C}-\mathrm{H}$ yang termasuk dalam kelompok gugus fungsi alkenes pada senyawa aliphatic hydrocarbon. Terdapat juga ikatan regangan methylene assymetric C-H. Ikatan C-H asimetri tidak dimiliki oleh bambu Ori. Namun bambu Ori memiliki 3 jenis ikatan $=\mathrm{C}-\mathrm{H}$ yang berbeda-beda daerah serapannya.

Hasil karakterisasi fase arang ketiga jenis bambu menggunakan XRD ditunjukkan Gambar 2. Difraktogram arang ketiga jenis bambu berupa satu puncak amorfus dengan perbedaan bentuk puncak. Hasil pengolahan data difraksi mengacu pola difraksi nomor PDF 00-041-1487, ketiga arang bambu memiliki fase reduced Graphene Oxide (rGO pada rentang sudut $2 \theta=(20-30)^{\circ}$ dengan bidang refleksi (002) dalam struktur grafit karbon amorf [9]. Fase rGO ini termasuk dalam tipe carbon graphite yang memiliki sistem kristal heksagonal dengan space group $\mathrm{P} 63 / \mathrm{mmc}$. Hal ini dikuatkan dengan hasil uji FTIR yang menyebutkan adanya gugus fungsi utama rGO yaitu ikatan $\mathrm{C}=\mathrm{C}$. Untuk arang bambu Petung memiliki refleksi bidang lain yaitu pada posisi puncak $2 \theta$ antara $(40-50)^{\circ}$, ini menunjukan fase rGO dalam arang bambu Petung lebih banyak terbentuk.

Grafena alam dari arang ketiga jenis bambu berfase rGO yang disintesis secara karbonisasi memiliki bentuk morfologi lembaran-lembaran tipis. Morfologi grafena berfase rGO dari arang bambu Petung terlihat berupa lembaran tipis yang lebih seragam dibanding kedua jenis bambu lainnya. Keseragaman ukuran menyebabkan luas permukaan partikel yang besar akan berdampak pada sifat listrik dan penyerapan gelombang mikro. Nilai konduktivitas listrik dari ketiga jenis arang bambu ditunjukkan pada Tabel II. Nilai konduktivitas listrik ketiga jenis arang bambu berfase rGO berkisar 5,57 


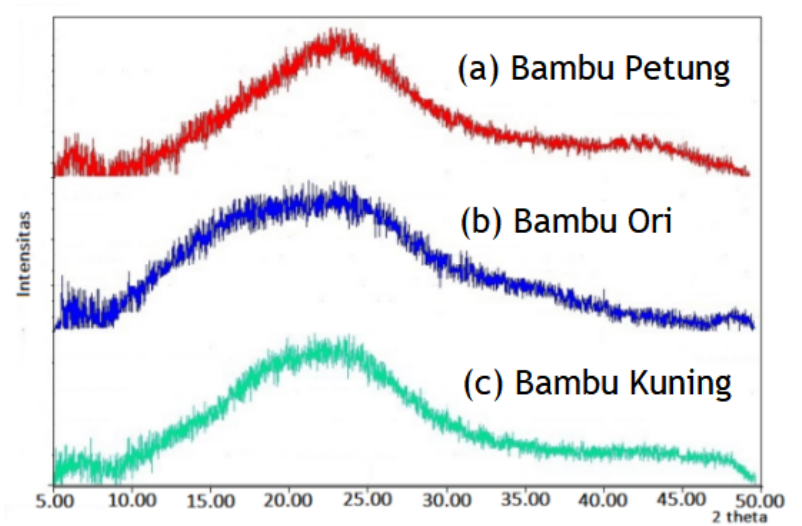

(a)

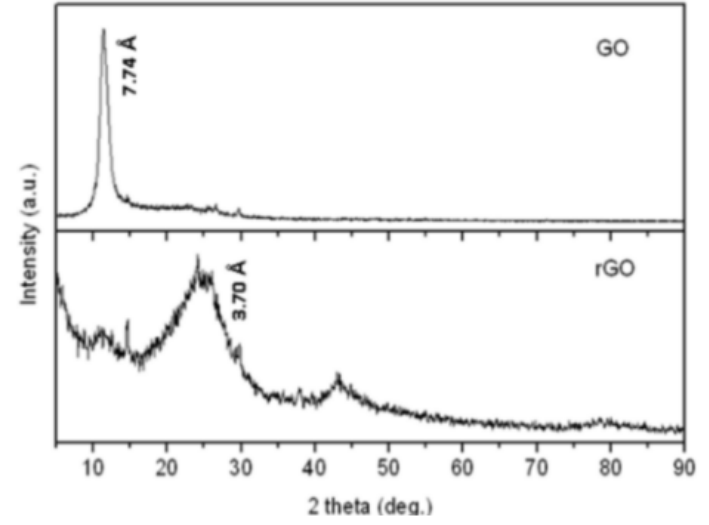

(b)

Gambar 2: Difraktogram (a) arang bambu, dan (b) fase GO / rGO [9].

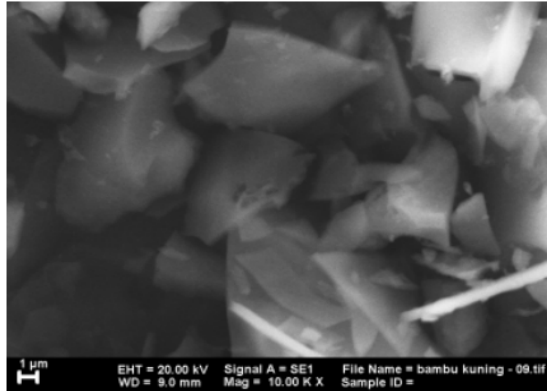

(a)

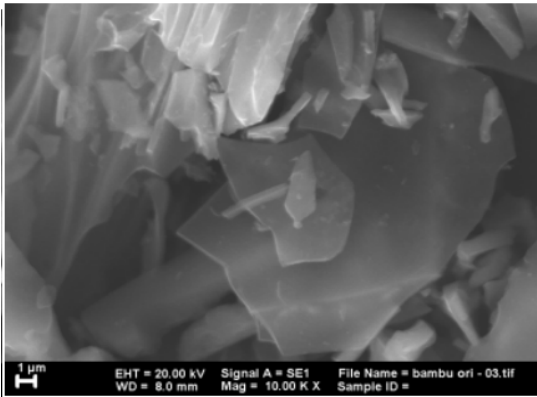

(b)

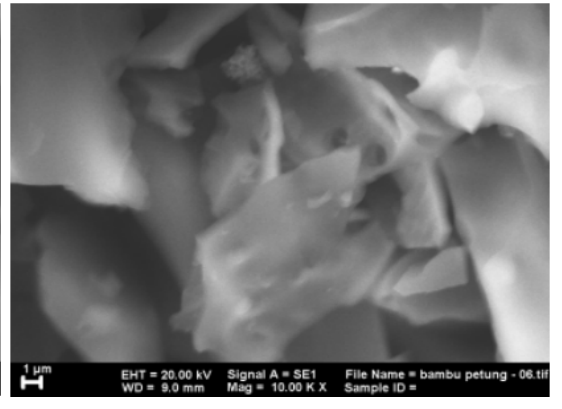

(c)

Gambar 3: Morfologi grafena alam dari arang bambu (a) Kuning, (b) Ori, (c) Petung.

$\times 10^{-6} \mathrm{~S} / \mathrm{m}$ termasuk dalam bahan semikonduktor [10]. Hal ini menunjukkan bahwa grafena alam dari arang ketiga jenis bambu memiliki dielektrisitas. Grafena alam dari arang bambu Petung memiliki nilai konduktivitas listrik yang paling tinggi walau tidak signifikan sehingga akan berdampak pada sifat penyerapan terhadap gelombang mikro.

\section{Analisis penyerapan gelombang mikro pada frekuensi 8-12 GHz}

Penyerapan gelombang mikro pada frekuensi 8-12 GHz dari grafena alam berfase rGO berbahan dasar arang bambu Kuning, Ori dan Petung diukur menggunakan alat VNA. Sampel diukur dengan ketebalan 0,3 mm, 0,6 mm dan 0,9 mm. Besarnya daya serapan terhadap gelombang mikro dilihat dari nilai maximum reflection loss $\left(\mathrm{RL}_{m}\right)$ yang menyatakan berapa besar daya yang tidak direfleksikan karena penyerapan. Hasil pengukuran dan penghitungan nilai maximum reflection loss $\left(\mathrm{RL}_{m}\right)$ dengan variasi jenis bambu dan ketebalan ditunjukkan Gambar 4. Nilai maximum reflection loss dihitung berdasar pada transmit-line theory menggunakan persamaan [11]:

$$
\begin{aligned}
R L_{m}(d B) & =20 \frac{\log \left(Z_{i n}-1\right)}{Z_{i n}+1} \\
Z_{i n} & =\sqrt{\frac{\mu_{r}}{\epsilon_{r}}} \tanh \left[j(2 \pi f d / c) \sqrt{\frac{\mu_{r}}{\epsilon_{r}}}\right]
\end{aligned}
$$

dengan $\mathrm{Z}_{i n}$ : impedansi datang pada absorber, f: frekuensi gelombang mikro, d: ketebalan, c: kecepatan gelombang mikro pada ruang hampa, $\mu_{r}$ : permeabilitas dan $\epsilon_{r}$ : permitivitas.

Analisis penyerapan gelombang mikro dengan mengacu nilai $\mathrm{RL}_{m}<-20 \mathrm{~dB}$ ( $99 \%$ energi terserap) maka grafena alam berfase rGO berbahan dasar bambu Kuning, Ori dan Petung memiliki daya penyerapan yang tinggi dan memiliki dual matching frequency $\left(\mathrm{f}_{m}\right)$ seperti yang ditunjukkan Tabel III. Ketebalan mempengaruhi penyerapan gelombang mikro di mana semakin tebal bahan penyerap dapat menurunkan nilai matching frequency dan meningkatkan penyerapan yang ditandai semakin kecilnya nilai maximum reflection loss. Hasil pengukuran menunjukkan penyerapan optimum oleh ketiga sampel terjadi pada ketebalan 0,6 mm. Hal ini sesuai teori bahwa penyerapan gelombang mikro optimum jika tebal lapisan sama dengan panjang gelombang mikro 


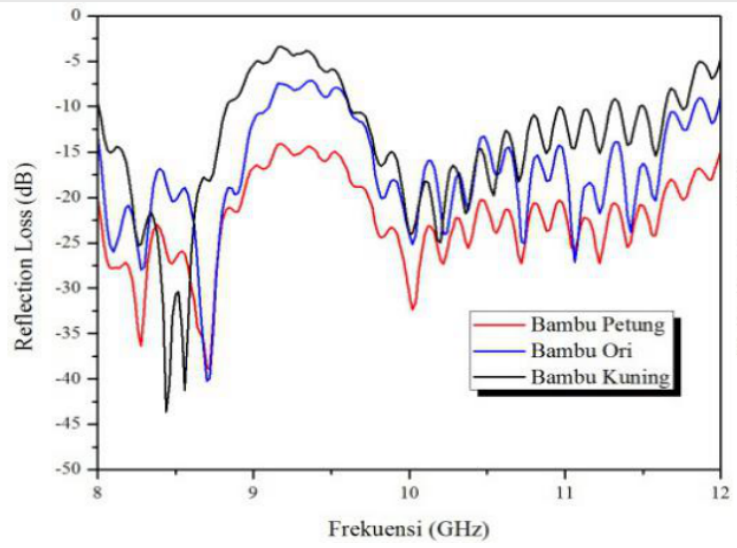

(a)

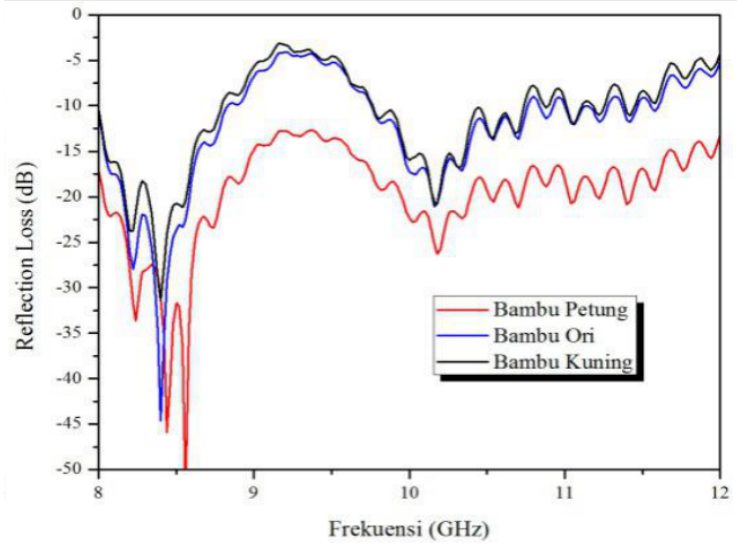

(b)

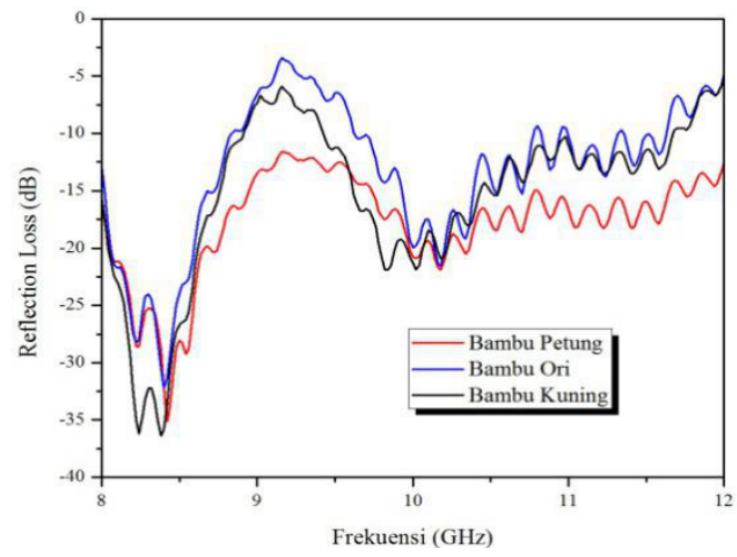

(c)

Gambar 4: Reflection Loss grafena berfase rGO dari arang bambu pada ketebalan (a) 0,3 mm, (b) 0,6 mm, (c) 0,9 mm.

TABEL III: Karakteristik penyerapan gelombang mikro grafena berfase rGO.

\begin{tabular}{|c|c|c|c|c|c|c|}
\hline Grafena rGO & $\mathrm{T} \quad \mathrm{eb}$ & oal $0,3 \mathrm{~mm}$ & T ebal $0,3 \mathrm{I}$ & Tebal $0,6 \mathrm{n}$ & T ebal 0,3 & aTebal 0,9 \\
\hline Arang Bambu & $\mathrm{RL}_{m}(\mathrm{~dB})$ & $\mathrm{f}_{m}(\mathrm{GHz})$ & $\mathrm{RL}_{m}(\mathrm{~dB})$ & $\mathrm{f}_{m}(\mathrm{GHz})$ & $\mathrm{RL}_{m}(\mathrm{~dB})$ & $\mathrm{f}_{m}(\mathrm{GHz})$ \\
\hline Petung & $-38,95$ & 8,72 & $-52,88$ & 8,56 & $-35,15$ & 8,42 \\
\hline & $-32,37$ & 10,02 & $-26,33$ & 10,18 & $-21,92$ & 10,18 \\
\hline Ori & $-40,19$ & 8,70 & $-45,46$ & 8,40 & $-24,91$ & 8,40 \\
\hline & $-28,79$ & 10,74 & $-25,15$ & 10,18 & $-19,31$ & 10,18 \\
\hline Kuning & $-42,72$ & 8,44 & $-34,15$ & 8,40 & $-27,10$ & 8,38 \\
\hline & $-28,73$ & 10,20 & $-25,46$ & 10,16 & $-19,50$ & 9,84 \\
\hline
\end{tabular}

pada frekuensi 8-12 GHz yakni $0,5 \mathrm{~mm}$. Penyerapan gelombang mikro dapat optimum juga ditentukan oleh nilai permitivitas relatif dan permeabilitas relatif bahan penyerap. Pada ketebalan yang sama $(0,6 \mathrm{~mm})$, daya penyerapan gelombang mikro grafena alam berfase rGO dari arang bambu Petung paling besar dibanding bambu Ori dan Kuning. Hal ini ditunjukkan oleh nilai $\mathrm{RL}_{m}$ dan $\mathrm{f}_{m}$ dari grafena alam rGO berbahan dasar bambu Petung $\left(\mathrm{RL}_{m 1}=-52,88 \mathrm{~dB}, \mathrm{f}_{m 1}=8,56 \mathrm{GHz}\right.$, $\left.\mathrm{RL}_{m 2}=-26,33 \mathrm{~dB}, \mathrm{f}_{m 2}=10,18 \mathrm{GHz}\right)$, Ori $\left(\mathrm{RL}_{m 1}=-45,46\right.$ $\left.\mathrm{dB}, \mathrm{f}_{m 1}=8,40 \mathrm{GHz}, \mathrm{RL}_{m 2}=-25,15 \mathrm{~dB}, \mathrm{f}_{m 2}=10,18 \mathrm{GHz}\right)$ dan Kuning ( $\mathrm{RL}_{m 1}=-34,15 \mathrm{~dB}, \mathrm{f}_{m 1}=8,40 \mathrm{GHz}, \mathrm{RL}_{m 2}=$ $\left.-25,46 \mathrm{~dB}, \mathrm{f}_{m 2}=10,16 \mathrm{GHz}\right)$. Hasil ini lebih baik dibanding
rGO berbahan dasar bambu Moso Cina penelitian K.H. Wu, et.al (2008) dengan $\mathrm{RL}_{m}=-7,5 \mathrm{~dB}, \mathrm{f}_{m}=6 \mathrm{GHz}$ dan komposit $\mathrm{Fe}_{3} \mathrm{O}_{4} / \mathrm{rGO}$ berbahan komersial dengan $\mathrm{RL}_{m}=-17,5 \mathrm{~dB}, \mathrm{f}_{m}$ $=6 \mathrm{GHz}$ dan tebal 1,9 mm oleh Ying Huang et.al (2016).

Penyerapan gelombang mikro oleh grafena alam berfase rGO dari ketiga arang jenis bambu tersebut disebabkan memiliki dielectric loss yang terbentuk oleh conductivity loss dan polarization loss. Polarization loss terdiri dari polarisasi ionik, polarisasi elektronik, polarisasi arah dipol dan polarisasi antar muka (space charge polarization) [12]. Polarisasi ionik dan elektronik terjadi pada frekuensi gelombang mikro bersesuaian konduktivitas listrik pada daerah semikon- 
duktor. Perbedaan kelektronegatifan antar atom dalam gugus fungsi dalam rGO akan membentuk dipol-dipol listrik. Ketika dipol-dipol listrik ini berinteraksi dengan gelombang mikro maka energi akan diserap melalui mekanisme polarisasi arah dipol secara periodik, selanjutnya energi dari gerak polarisasi arah dipol terkonversi menjadi energi panas. Penyerapan gelombang mikro juga terjadi pada permukaan oleh momen listrik makroskopik dari rGO yang disebut polarisasi antar muka. Grafena berfase rGO yang disintesis dari bambu Kuning, Ori dan Petung memiliki daya penyerapan tinggi pada selang frekuensi 8-12 GHz dengan nilai reflection loss $<$ 20 dB. Namun bahan dasar arang bambu Petung memiliki daya serapan lebih baik dari bambu Kuning dan Ori, hal ini dimungkinkan karena morfologi serbuk yang relatif lebih seragam sehingga polarisasi dipol listrik berlangsung lebih mudah sehingga penyerapan energi gelombang mikro dapat terjadi lebih efektif. pada temperatur $600^{\circ} \mathrm{C}$ selama 45 menit, memiliki nilai konduktivitas listrik $5,5 \times 10^{-6} \mathrm{~S} / \mathrm{m}$. Grafena alam berfase rGO dari arang bambu berpotensi sebagai bahan penyerap gelombang mikro (8-12 GHz) yang baik dengan nilai maximum reflection loss $\left(\mathrm{RL}_{m}\right)<-20 \mathrm{~dB}$ dan terjadi pada dual matching frequency $\left(\mathrm{f}_{m}\right)$. Penyerapan terhadap gelombang mikro terbesar terjadi pada ketebalan optimum 0,6 mm dengan nilai $\mathrm{RL}_{m}$ dan $\mathrm{f}_{m}$ secara berturut arang bambu Petung $\left(\mathrm{RL}_{m 1}=-52,88 \mathrm{~dB}, \mathrm{f}_{m 1}=8,56 \mathrm{GHz}, \mathrm{RL}_{m 2}=-26,33 \mathrm{~dB}\right.$, $\left.\mathrm{f}_{m 2}=10,18 \mathrm{GHz}\right)$, Ori $\left(\mathrm{RL}_{m 1}=-45,46 \mathrm{~dB}, \mathrm{f}_{m 1}=8,40 \mathrm{GHz}\right.$, $\left.\mathrm{RL}_{m 2}=-25,15 \mathrm{~dB}, \mathrm{f}_{m 2}=10,18 \mathrm{GHz}\right)$ dan Kuning $\left(\mathrm{RL}_{m 1}=\right.$ $-34,15 \mathrm{~dB}, \mathrm{f}_{m 1}=8,40 \mathrm{GHz}, \mathrm{RL}_{m 2}=-25,46 \mathrm{~dB}, \mathrm{f}_{m 2}=10,16$ $\mathrm{GHz}$ ). Bambu Petung sangat potensial dijadikan sebagai bahan penyerap gelombang mikro dalam bentuk grafena alam berfase rGO bersifat ramah lingkungan, relatif murah dan sederhana pembuatannya.

\section{Ucapan Terima Kasih}

Grafena alam berfase reduced Graphene Oxide (rGO) berorde mikrometer dapat disintesis dari arang bambu Kuning, Ori, dan Petung menggunakan metode karbonisasi
Kami mengucapkan terima kasih kepada Kemenristekdikti yang telah memberikan pendanaan penelitian melalui program Hibah Penelitian PDUPT tahun anggaran 2020.
[1] N. Yousefi, et al., "Highly Aligned Graphene/Polymer Nanocomposites with Excellent Dielectric Properties for HighPerformance Electromagnetic Interference Shielding", Advanced Materials, vol. 26, pp. 5480-5487, 2014.

[2] Y. Huang, et al., "Magnetic reduced graphene oxide nanocomposite as an effective electromagnetic wave absorber and its absorbing mechanism", Ceramics International, vol. 42, pp. 17116-17122, 2016

[3] I. Choi, D. Lee, D.G. Lee, "Optimum Design Method of a Nano-Composite Radar Absorbing Structure Considering Dielectric Properties in the X-Band Frequency Range", Composites Structure, vol. 119, pp. 218-226, 2015.

[4] B. Zhang, et al., "Microwave absorption properties of lightweight absorber based on Fe50Ni50 coated poly(acrylonitrile) microspheres and reduced grapheme oxide composites", Journal of Magnetism and Magnetic Materials, vol. 413, pp. 81-88, 2016.

[5] E. Ma, et al., "Preparation of reduced graphene oxide/ $/ \mathrm{Fe}_{3} \mathrm{O}_{4}$ nanocomposite and its microwave electromagnetic properties", Materials Letters, vol. 91, pp. 209-212, 2013.

[6] L. Zhu, et al., "Hydrothermal synthesis of magnetic $\mathrm{Fe}_{3} \mathrm{O}_{4} /$ graphene composites with good electromagnetic microwave ab- sorbing performances", Journal of Magnetism and Magnetic Materials, vol. 426, pp. 114-120, 2017.

[7] Y. Wang, et al., "Controlled synthesis and electromagnetic wave absorption properties of core-shell $\mathrm{Fe}_{3} \mathrm{O}_{4} 4 @ \mathrm{SiO}_{2}$ nanospheres decorated grapheme", Ceramics international, vol. 43, pp. 1887-1894, 2017.

[8] Krisdianto, G. Sumarni, A. Ismanto, "Sari Hasil Penelitian Bambu", Departemen Kehutanan, Jakarta, 2000.

[9] C. Fu, et al., "Evaluation and characterization of reduced graphene oxide nanosheets as anode materials for lithium-ion batteries", International Journal of Electrochemical Science, vol. 8, pp. 269-6280, 2013.

[10] C.-C. Chen, et al., "Microwave absorbing properties of flakeshaped carbonyl iron/reduced grapheme oxide/epoxy composites", Materials Research Bulletin, vol. 96, pp. 81-85, 2017.

[11] K.H. Wu, et al., "Synthesis and microwave electromagnetic characteristics of bamboo charcoal/polyaniline composites in 240GHz". Synthetic Metals, vol. 158, pp. 688-694, 2008.

[12] F. Meng, et al., "Graphene-based microwave absorbing composites: A review and prospective", Composites Part B, vol. 137, pp. 260-277, 2018. 